\title{
SNAP-TENTACLES AND RUNWAY LIGHTS: \\ SUMMARY OF COMPARATIVE EXAMINATION OF DROSERA TENTACLES
}

\author{
IRMGARD AND Siegfried R.H. HARTMEYeR • Wittlinger Str. 5 • 79576 Weil am Rhein • Germany \\ •www.hartmeyer.de
}

Keywords: Droseraceae, D rosera glanduligera, D. hartmeyerorum, lens-tentacles, snap-tentacles, systematics

\section{Introduction}

$M$ any $C P$-books describe the trapping mechanism of D rosera generally as leaves with sticky stalked glands, which are able to bend towards the caught prey. However, the traps are actually not that simple. Even as early as 1875 , Charles Darwin, in his book "The Insectivorous Plants" (Darwin 1888) and a few later scientific publications mention two different tentacle structures for D rosera rotundifolia. Since 2003, we have published information showing the morphology of D rosera tentacles is actually even more sophisticated (Hartmeyer 2003, 2004; Hartmeyer \& Hartmeyer 2005, 2006a-d, 2008a, b). As of December 2009, we have investigated more than 100 world-wide distributed species and varieties. From this work, we concluded that the term "stalked glands", often used as synonym for all D rosera tentacles, must be considered as much too simplifying and even incorrect in many cases. A good example is the A ustralian Pimpernel Sundew (D. glanduligera Lehm.), published by Lehman in 1844 (see Front Cover). In the early 1970s, a nine-year-old young boy named Richard Davion found that the elongated marginal tentacles of $D$. glanduligera, which was growing close to his property in A delaide, moved within fractions of a second. B ut like Lehman's description, the carnivorous plant literature (i.e. Erickson 1968 and Lowrie 1989) described the plant as a common sundew, and so for many years nobody believed this young A ustralian.

In 2003, Davion mailed his private video-shots of the phenomenon, including some seeds, asking us to confirm his observation. Equipped with camcorder and USB-microscope, we examined the minute, always hungry and absolutely nasty to cultivate sundew, during two winter seasons. By 2005, we had collected enough material to fully confirm Davion's observations and to publish even more amazing features, such as the unique ontogenetic development (Hartmeyer \& Hartmeyer 2005). We were also able to produce our Hunting Veggies ${ }^{\circledR}$ videos and to describe the conditions necessary to cultivate that "diva", which is considered by some experts as a kind of missing link between the sticky traps and the snap-traps in family Droseraceae. To our surprise, merging this awareness with our continuing experiments with other "snaptentacle sundews", produced a clear view of the relations between, and even the phylogeny of, the D roseraceae based on their easily recognized different trap structures. One more result was the understanding of the morphology and function of the odd yellow lens-tentacles on the leaves and bracts of D. hartmeyerorum Schlauer (Schlauer 2001). So now, four years after our DV D "D rosera: Snap-Tentacles and Runway Lights" (Hartmeyer \& Hartmeyer 2006) was shown at the ICPS conference 2006 in Frostburg - which documents this work until 2005-, it's a pleasure for us to now provide a detailed summary of our comparative examinations on D rosera tentacles for CPN. 
Talking about the ability of some species of carnivorous plants to catch prey with active moving traps has been of high interest for a long time. Therefore, it is actually amazing that the easily observed fast movement, and the differing morphology, of marginal Drosera tentacles, especially with several eye-catching pygmy Drosera (section Bryastrum, Lamprolepis), has been badly neglected, or simply ignored-even with the publication of new species in recent literature- at least until our publication in early 2005 on a sundew possessing a true snap-mechanism (Hartmeyer \& Hartmeyer 2005). The scientific book "The Carnivorous Plants" (J uniper et al. 1989) mentions that several species exist which develop rapid moving, glue-less marginal tentacles (e.g. D. burmannii), putting them into a context of evolution from D rosera tentacles to the snap trap of Dionaea. B ut as mentioned, even the old authors knew about the non-glandular tentacles of D. rotundifolia. B eside Charles Darwin's first remarks in "Insectivorous Plants" (Darwin 1888), descriptions are mostly restricted to a few scientific publications in professional journals, such as Flora (1904), where C.A. Fenner (Germany) provided wonderful and very detailed botanical drawings of $D$. rotundifolia and other carnivorous genera (Fenner 1904). Investigations on the movement of D rosera tentacles and how close they are related to the trigger hairs of Aldrovanda and Dionaea have been published by Prof. Stephen Williams (USA) in the early 1970s (Williams 1976, 2002; W illiams \& Pickard 1974, 1979). U sing minute electrodes, he measured action potentials produced at the head or at the junction between head and stalk by touching or chemical stimulation (i.e. with sodium chloride) of the tentacle head. The action potentials move down the stalk where they cause particular cell-groups to increase their inner pressure. Without any junction, the whole tentacle starts bending inward toward the lamina due to rapid cell expansion (called turgor-growth). Stephen Williams examined mucilage producing tentacles of D. capensis for his experiments. In the early $20^{\text {th }}$ century, Henry D. Hooker, J r. (1917) used the fitting term "non-glandular bisymmetric tentacle head" and dedicated his research on "the mechanics of movement in Drosera rotundifolia" mainly to the bending stalks of its marginal tentacles. In 1972, H.W.J. Ragetli, M. Weintraub, and Esther Lo (Ragetli et al. 1972) described two tentacle structures for the D rosera trap “... bisymmetrical tentacles lying in the plane of the leaf blade and extending outward from the leaf margin; and radially or nearly radially symmetrical tentacles extending upwards from the upper surface of the leaf ... composed of an oval shaped head, a cylindrical stalk, and a connecting zone". However, it was worth it to examine numerous species again, because our results show clearly that there are not only more, but even really amazing, adapted tentacles with clearly different morphology.

\section{D rosera glanduligera, the snap-trap sundew}

In 1994, we filmed D rosera burmannii (section Thelocalyx) in our greenhouse to record the rapid movement of its non-glandular elongated marginal tentacles (Hartmeyer $\&$ Hartmeyer 2006). Surprisingly, we also found such tentacles with some other sundews standing nearby. A ctually, less eye catching, but showing the same tactic, were the hybrids $D$. capensis $\times$ aliciae and $D$. rotundifolia $\times$ spatulata (synonym: D. tokaiensis), some A frican species (section D rosera), as well as some pygmy Drosera (section Bryastrum/Lamprolepis). We found it very interesting that some species showed this feature and others not. We kept the phenomenon in mind for a future project.

In 2003, we received the above mentioned parcel from Richard D avion. He wrote about "R ibbon Tentacles" on D. glanduligera (monotypic section C oelophylla) which need only fractional parts of a second to bend. In 1995 and 1999, he even published articles on the subject in "Flytrap News" 
(D avion 1995, 1999) mentioning al so the movement of D. burmannii, D. pygmaea, and D. callistos. This proved to be in vain, because obviously CP enthusiasts either ignored or did not believe him - until we showed his VHS recordings on our DV D "A Hunting Veggies Cocktail" (Hartmeyer \& Hartmeyer 2004). For our own experiments, we used a PA L video camera (25 pictures per second) for speed measurements and were able to prove with single pictures that, triggered with a tooth pick or tweezers, D. glanduligera moves its elongated marginal tentacles within sensational 0.16 $( \pm 0.04)$ seconds like a snap trap, which set a unique record for the genus and is as fast as the Venus Flytrap snaps shut. In addition, our attendant microscope pictures show a clearly distinct tentacle morphology (see below), again unique for the whole genus. A lso, the ontogenetic development of its seedlings is clearly different from other species. So we thoroughly confirmed Davion's discovery, and wrote an article for the German CPS (GFP) newsletter Das Taublatt (Hartmeyer \& Hartmeyer 2005). With our publication, we coined the term "snap-tentacle" in English and, after a proposal by Dr. J an Schlauer, the term "Schnelltentakel" in the German language. A new video showing the snap-tentacles of D. glanduligera in action can meanwhile be seen on YouTube (D rosera glanduligera snap-tentacles: http://www.youtube.com/watch?v=_q4daCCHKoQ).

\section{A new diversity of tentacles}

A Iready in the early state of our experiments with rapid moving marginal tentacles, but increasingly after our examination of D. glanduligera, our macro-shots and microscope pictures disclosed a clandestine diversity, demanding an even closer inspection. A mazed about different shapes, speed, and the spasmodic appearance even in closely related species, we realized that these results contain not only obvious information about adaptation and relationship within the genus, but also on the evolution of the whole family Droseraceae.

B eside the "normal" symmetrical mucilage-producing tentacles growing upright on the lamina, we identified three different types of marginal tentacles. We also found additional non-glandular structures like the unique yellow-shining lens-headed tentacles at the base of the trapping leaves and at the bracts of the florescence of $D$. hartmeyerorum (section Arachnopus). The head consists of lens-like transparent giant cells focusing at a bright yellow cell-structure in the center. Reflecting the incoming sunlight, these lens-tentacles function like a yellow rear reflector (Hartmeyer \& Hartmeyer 2006). A dditional lens-tentacles, placed at intervals on the dark red bracts of the green florescence, look like a chain of runway lights from above, attracting insects (we found lots of baby grasshoppers) to walk or skip down the flower stalk into the dark red and sticky plant center from where bundles of lens-tentacles show the yellow lightning with high contrast. We also found different small 0.1 to $1 \mathrm{~mm}$-sized emergences with a simple yellow hemisphere-shaped head on the trapping leaves and stalk of A ustralian D. indica, and translucent mushroom-like emergences with a waved flat head on a large A frican D. indica (Hartmeyer 2003; Hartmeyer \& Hartmeyer 2006). We guess that the mushroom-like structures produce the sweet odor of that intensely scented plant. From personal communication, we know about some more different emergences on sundews which are still subject to further examination and have not been published yet. O ur examinations on the lens-tentacles can meanwhile be seen on YouTube: "Sophisticated survival strategies of the annual D rosera" http://www.youtube.com/watch?v=_TkGTiqkDIY.

These findings produce an increased understanding about the connection of marginal tentacles with the other genera assigned to the D roseraceae: Aldrovanda and Dionaea. Their modified nonglandular tentacles should not be forgotten. These are the trigger hairs on the snap-traps of both genera that developed from D rosera tentacles, as Stephen Williams described in the 1970s. But, also, 


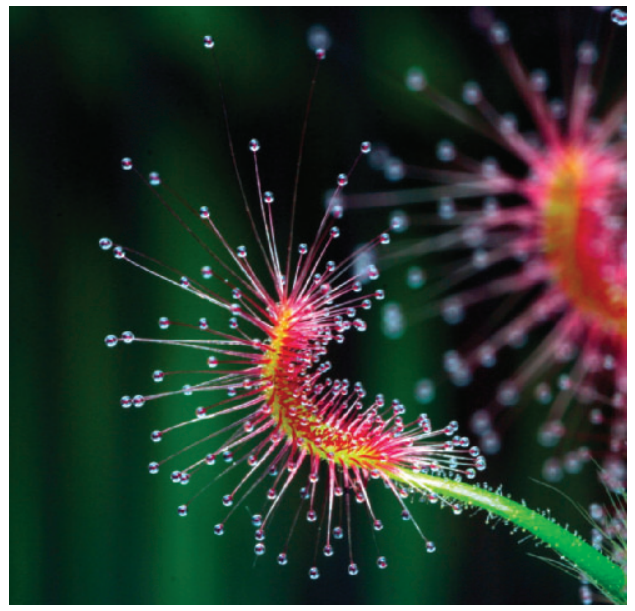

Figure 1: Drosera scorpioides, T1 sticky marginal tentacles. Photo by E. Pöhlmann. the spine-like teeth on the margin of Dionaea lobes are obviously a remnant of marginal tentacles which lost their (no longer needed) trigger function.

\section{Three different types of marginal tentacles}

Concerning the rapid moving marginal tentacles of D rosera, we confine ourselves only to the three types of "modern" tentacles that all emerge with a very broad and powerful base (four to six times broader than the base of the cylindrical tentacle stalks on the lamina) lying in the plane of the leaf blade. The following definition was published in 2008 (Hartmeyer \& Hartmeyer 2008; M cPherson 2008).

The first type of marginal tentacles (T1, present mainly on the leaves of erect growing species) possess a mucilage producing, glandular symmetrical head which is similar to the normal stalked mucus secreting glands on the lamina of that species, however, develops on an elongated stalk that emerges with a very broad base. This type of el ongated marginal tentacle is typified on the lamina of D. scorpioides for example (see Figure 1). M ovement in this type of tentacle takes place by turgor growth.

The second type of marginal tentacle (T2, present mainly on the leaves of basal rosettes) possess a bisymmetrical, non-glandular head that lacks a sticky mucus secretion, often looking somewhat like a shovel with a flat lower side and an elevated mostly red, rarely green colored cushion-like glandless cell structure on the upper side, which develops on an elongated stalk that emerges with a very broad base. The size and shape of the el ongated head and stalk vary considerably within different species. This type of elongated marginal tentacle is typified on the lamina of D. burmannii for example (see Figure 2). Important: T2- tentacles always lack secretions of glue and movement takes place by turgor growth.

The third type of marginal tentacle (T3) is known only from D. glanduligera (see Figure 3). The stalk consists of a broad lower section emerging with a very broad base from the margin of the lamina and, connected by a kind of junction, a very slender but longer upper portion that terminates in a bisymmetrical, non-glandular head that lacks sticky mucus (see Figures 4 and 5). Evidently, the tentacle head contains a trigger mechanism, which when activated, causes the tentacle to move very rapidly. The slender upper part of the tentacle bends forward from the junction-like midsection so that the head of the tentacle snaps towards the middle of the lamina (see Figure 6). The whole process takes place remarkably quickly; we measured 0.16 seconds. The process of movement and the morphology of T3-tentacles differ therefore from all other tentacles known from the foliage of species of D rosera. The mechanism by which movement takes place is not currently understood. It is possible that some turgor grow th takes place in order for the tentacle to bend, however, the process overall is much more sophisticated and therefore D. glanduligera is (until today) the only sundew that moves with the same speed as the Venus Flytrap.

We define a snap-tentacle (T2 + T3) as a structure which emerges with a powerful broad base from the margin of the lamina, consists of an elongated stalk with or without junction, and a bi- 
symmetrical non-glandular head. This definition includes the second and third type of elongated marginal tentacles described above, but not the first type, as despite its powerful broad base and often rapid movement, T1 carries a mucilage producing, glandular symmetrical head (much like those of regular tentacles common to the leaves of all species of Drosera). Any tentacle with a conventional mucus secreting head is therefore not a snaptentacle.

Both types of snap-tentacles are able to bend rapidly, although through different processes and at very different speeds. T3-tentacles move 50 to 100 times faster than T2-tentacles. Since both types are non-glandular, it seems likely that they primarily play the role of ensuring and fixing prey to the center of the lamina, and so, to complicate an escape and/or to avoid the theft of prey by cleptoparasites. Not to forget, usually behind the front row of snap-tentacles follow 1-3 rows with smaller and more upright-held sticky T1 tentacles, which develop also with the typical broad base (unlike the normal upright gluetentacles on the lamina) and support the snaptentacles in fixing prey.

\section{A rchaic and modern Drosera}

During our experiments, it became clear that the ontogenetic development of the seed-

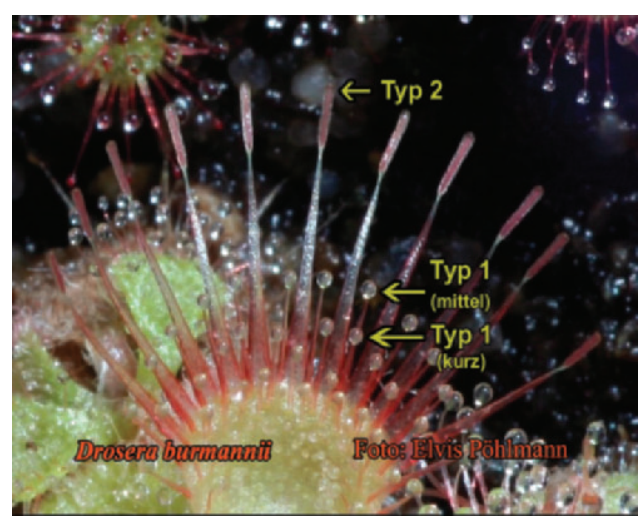

Figure 2: Drosera burmannii, T2 + T1 tentacle pattern on adult plant. Annotated by $S$. Hartmeyer.

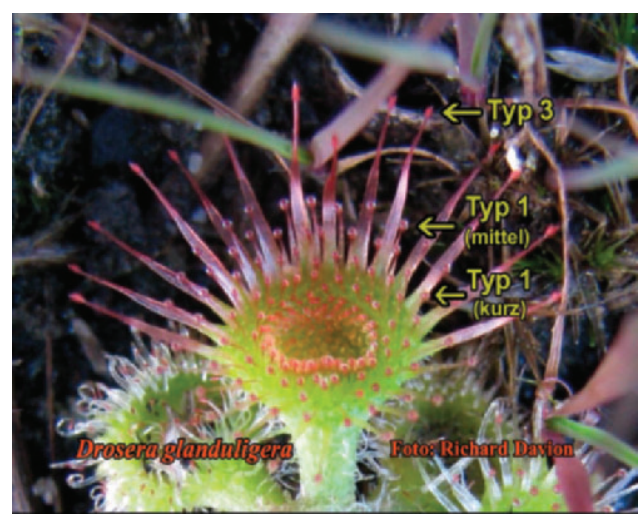

Figure 3: Drosera glanduligera, T3 + T1 tentacle pattern on adult plant. Annotated by S. Hartmeyer.

lings also deserves a closer investigation. Surprisingly, many seedlings possess leaf generations (which follow the cotyledons) with a minimum of three to five powerful snap-tentacles (T2) which emerge morphologically as outgrowth of the lamina, but many of the adult plants do not.

U nfortunately, we were not able to get seeds from D. arcturi, D. regia, and section Prolifera. Therefore, these species were examined for snap-tentacles looking at the first leaves of small plantlets, which grew from root- or leaf-cuttings (D. adelae, D. regia, and D. schizandra), developed at the florescence (D. prolifera), or opened first from winter resting buds ( $D$. arcturi). The results show clearly that juvenile plants of the oldest known species in the genus, D. arcturi and D. regia, never develop broad-based marginal tentacles (T1-T3). This confirms the assumption that the first sundews caught their prey only with simple glue-tentacles on the lamina, but had al ready developed the ability to roll the complete leaf.

A Iso, the species in section A rachnopus (D. hartmeyerorum, D. indica), and section Prolifera (D. adelae, D. prolifera, D. schizandra) seem to descend from archaic species because here we found no snap-tentacles. However, one exception in section Prolifera is D. adelae, which pos- 


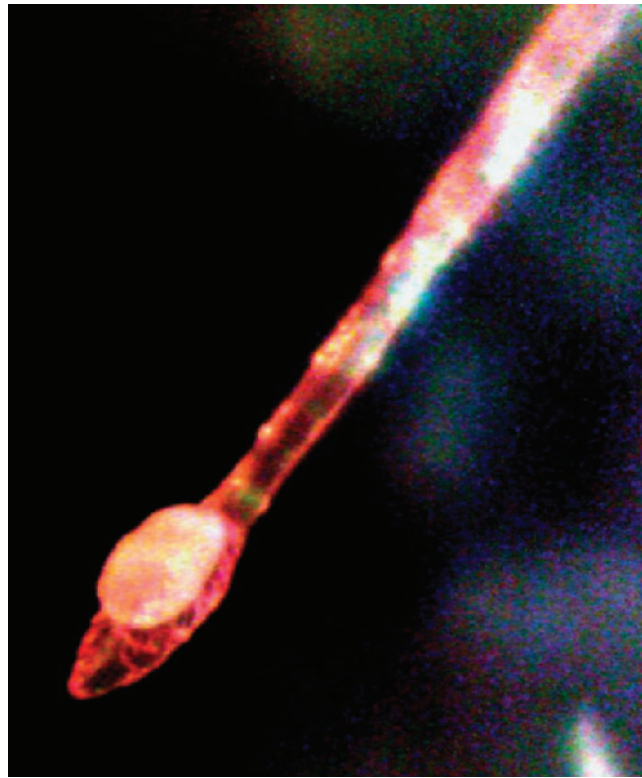

Figure 4: Drosera glanduligera, tentacle head. Photo by S. Hartmeyer.

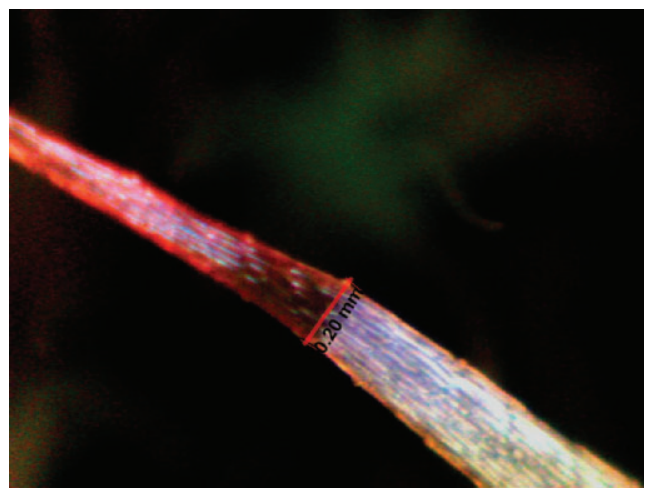

Figure 5: Drosera glanduligera, outstretched snap-tentacle with junction in the middle. Photo by S. Hartmeyer. sess some tentacles at the leaf-tips which also emerge from a broad base and are able to move faster (45-90 seconds) than the other tentacles on the lamina; therefore, they show some similarity to $\mathrm{T} 1$ tentacles. This may be a sign that section Prolifera is somehow in between the archaic and modern Drosera, but its tentacle structure is more closely related to the modern section Drosera than to section Arachnopus. This would also subsequently confirm Jan Schlauer's decision (Schlauer 1996) to extract the Q ueensland sundews from section Arachnopus into its own section Prolifera. Unlike all species which developed elongated marginal tentacles to fix prey to avoid theft by clepto-parasites, the species in section Arachnopus adapted and optimized their tentacles obviously to increase the attraction of prey.

The tuberous sundews (section Ergaleium) deserve further attention. N either seedlings nor adult plants possess snap-tentacles $(\mathrm{T} 2+\mathrm{T} 3)$, but mainly the erect species show typical broad-based marginal T1-tentacles. A s we documented with D. macrantha (Hartmeyer \& Hartmeyer 2006), when triggered, they bend with about the speed of $D$. burmannii. This is actually a very modern feature.

Without a doubt, something substantial must have happened in the past that triggered the development of powerful broad-based marginal tentacles to fix prey to the lamina, maybe to improve digestion, but more likely to complicate the theft of prey. With this important adaptation, the modern D rosera
(examined) species world-wide assigned to the turned up, becoming so successful that nowadays all (examined) species world-wide assigned to the
sections Bryastrum/Lamprolepis, D rosera, Lasiocephala, M eristocaulis, Phycopsis, P tycnostigma, Stel ogyne, and Thelocalyx descend from the first modern sundews, all starting their life as a seedling equipped with powerful T2 snap-tentacles.

Therefore, we define all species which develop either T1- or T2- or T3-tentacles as modern D rosera and those without these broad based marginal tentacles as archaic D rosera (see Table 1).

As mentioned above, D. glanduligera develops very effective and unique tentacles. At a first glance, the fastest snap-mechanism of the genus seems to be the most sophisticated and, therefore, very modern. U sing a magnifying glass, we observed that minute springtails were catapulted into 
the sticky center of the lamina after touching the unique snap-tentacle extending from the lamina - like the alarm threads of some spiders. But strange enough, its seedlings start with first leafgenerations (after the cotyledons) that possess only $\mathrm{T} 1$ stalked glands, even the next two or three leaf generations show only gluey and intermediate (between T1 \& T3) tentacles. Only from the fourth or fifth leaf generation on, the typical rapid moving snap-tentacles with the junction-like middlepart function are found. Therefore, the ontogenetic development is distinct from all other species (examined so far) in the genus and therefore D. glanduligera must be considered as the oldest of the described modern sundews.

\section{Basal rosettes and erect plants}

In section Bryastrum/Lamprolepis, for example, we find a lot of adult plants that possess very prominent snap-tentacles, but closely related species growing sometimes at the same site, do not. This confusion disappears immediately if the growing shape is taken in consideration, as show $n$ in Table 2. This pattern is typical for the species assigned to the modern sections and shows clearly that snap-tentacles are very important for seedlings and basal rosettes, but obviously not for erect plants. If the fixing of prey to the lamina would have been developed only to improve digestion, it should be useful for both basal and erect plants, but if the fixation is a strategy to avoid the theft of prey - which happens frequently, for example, by ants- the strategy is only important for trapping leaves near the soil (i.e., seedlings and basal rosettes). Erect growing plants, like D. scorpioides or D. madagascariensis, but also erect-held leaves, such as on adult $D$. capensis or D. binata (all seedlings and juvenile plants possess T2-tentacles), catch mostly flying insects, for which their sticky T1-tentacles work much more effectively. J ust a little contact with the tip of a wing is sufficient to paste and hold a mosquito. The speed of movement achieved by $\mathrm{T} 2$-tentacles may be impressive for a plant, but is certainly not dangerous for flying insects.

\section{D rosera of the N orthern Hemisphere}

R eferring to the whole genus, only a small number of species grow in the N orthern Hemisphere. While species like $D$. capillaris and $D$. spatulata remain relatively south, preferring warmer temperatures, D. anglica, D. intermedia, D. linearis, D. rotundifolia, and a little less tough D. filiformis, show a perfect adaptation to frost and short growing seasons by developing a true dormant

Table 1. Distribution of snap-tentacles (T2 \& T3) in Drosera sections (incl. seedlings).

\begin{tabular}{|l|c|l|c|}
\hline \multicolumn{1}{|c|}{ Section } & Snap-tentadetype & \multicolumn{1}{c|}{ Section } & Snap-tentadetype \\
\hline Arachnopus & -- & M eristocaulis & T2 \\
\hline Arcturi & -- & Phycopsis & T2 \\
\hline Bryastrum/L amprolepis & T2 & Prolifera & - - \\
\hline Coelophylla & T3 & Ptycnostigma & T2 \\
\hline Drosera & T2 & Regia & - - \\
\hline Ergaleium & -- & Stelogyne & T2 \\
\hline Lasiocephala & T2 & Thelocalyx & T2 \\
\hline
\end{tabular}




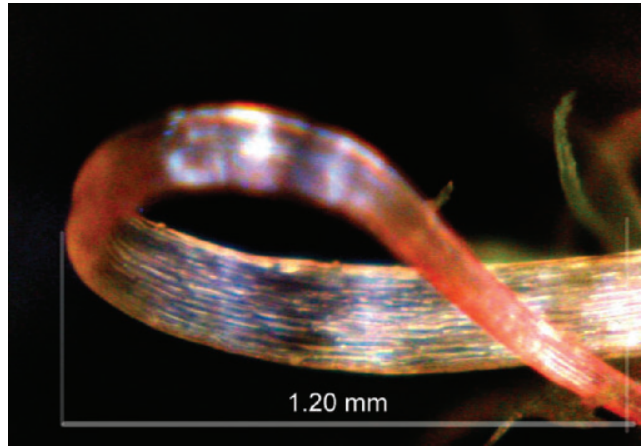

Figure 6: Drosera glanduligera, triggered snap-tentacle, bend at the junction. Photo by S. Hartmeyer.

bud. All species are assigned to the modern section Drosera and all of their seedlings possess snap-tentacles. However, the only typical basal rosette is $D$. rotundifolia, and confirming the above mentioned pattern for the growing shape, only this true northern species develops T2-tentacles on adult leaves not always and not every leaf, which caused a little confusion when we examined our greenhouse plants for our video and found not one snap-tentacle on any of our plants. But in the next season- after the video has been edited-the same plants developed them. N one of the species growing in colder regions of the Southern Hemisphere, neither

the simple winter bud of $D$. arcturi nor the thickened roots of $D$. binata or $D$. cistiflora are able to survive temperatures bel ow -20 or even -30 degrees centigrade, which is no problem for the specialized hibernacula of the northern species. A less effective adaptation to frost in the Southern Hemisphere is not illogical if one considers that the northern ice shields moved much further south (and back), occupying much more land than the A ntarctic ice shields, which show even today still about $80 \%$ of their maximum extension during the last glacial period about 20,000 years ago. So we can assume that the species of the Northern Hemisphere developed their strategies to survive extreme frost during the approximately 30 glacial periods within the last 2 million years.

\section{D rosera of the Southern Hemisphere}

The predominate number of D rosera can be found in the Southern Hemisphere. D. regia in South A frica and D. arcturi in A ustralia/N ew Zealand are the oldest known species and most experts agree that the genus devel oped in the south, spreading north over the course of time. As mentioned above, only modern species can be found north of A ustralia and South A frica, and surprisingly, the shape of their T2-tentacles seems to provide further information about their history. H owever, most T2-heads on seedlings and young leaves are round, or in D. binata sometimes nearly square, so only the shape of heads on adult leaves should be compared.

Let's start in A ustralia, where we find more than 100 of the approximately 180 species worldwide (estimated, because new species are frequently found). As mentioned above, D. glanduligera, due to its ontogenetic development, is probably the oldest of the modern Drosera. The greatest morphological similarity with the unique T3-tentacles of D. glanduligera, and therefore indicating the closest relationship, are the T2-tentacle heads of pygmy D rosera, where we find also very long slender stalks with minute round heads. A ctually, we also found the fastest T2-movement in this section with $D$. ericksoniae. Five seconds to bend to the lamina is indeed fast, however, still a magnitude slower than D. glanduligera. The large dichotomous leaves of D. binata (section P hycopsis) possess only mucus-producing T 1-tentacles, but seedlings and juvenile plants develop T2-tentacles until the lamina starts to divide.

Drosera burmannii, with very prominent snap-tentacles, shows the largest rectangular heads in the genus, referring to the plant size. It was in the past often called the fastest moving sundew, but with 8-15 seconds measured it is not faster than many pygmys. The only species in Australia 


\begin{tabular}{|c|c|c|c|c|}
\hline Section & Species & Seedling & Adult & Growing shape \\
\hline Arachnopus & D. hartmeyerorum & $\ldots$ & Lens-tentacles & Erect \\
\hline “ & $\begin{array}{l}\text { D. indica (all varieties, } \\
\text { probably even } \\
\text { undescribed species) }\end{array}$ & -- & $\begin{array}{l}\text { different small } \\
\text { emergences }\end{array}$ & Erect \\
\hline Arcturi & D. arcturi & -- & -- & $\begin{array}{c}\text { Rosette, erect } \\
\text { leaves }\end{array}$ \\
\hline Bryastrum/L amprolepis & D. callistos & $\mathrm{T} 2$ & $\mathrm{~T} 2$ & Basal rosette \\
\hline “ & D. ericksoniae & $\mathrm{T} 2$ & $\mathrm{~T} 2$ & Basal rosette \\
\hline$"$ & D. occidentalis & $\mathrm{T} 2$ & $\mathrm{~T} 2$ & Basal rosette \\
\hline$"$ & D. pulchella & $\mathrm{T} 2$ & $\mathrm{~T} 2$ & Basal rosette \\
\hline$"$ & D. pygmaea & $\mathrm{T} 2$ & $\mathrm{~T} 2$ & Basal rosette \\
\hline$"$ & D. dichrosepala & $\mathrm{T} 2$ & $\mathrm{T1}$ & Erect \\
\hline$" “$ & D. enodes & $\mathrm{T} 2$ & $\mathrm{T1}$ & Erect \\
\hline$"$ & D. lasiantha & $\mathrm{T} 2$ & $\mathrm{T1}$ & Erect \\
\hline$"$ & D. scorpioides & $\mathrm{T} 2$ & $\mathrm{T1}$ & Erect \\
\hline Coelophylla & D. glanduligera & $\mathrm{T} 1$ & T3 & Basal rosette \\
\hline Drosera & D. aliciae & $\mathrm{T} 2$ & $\mathrm{~T} 2$ & Basal rosette \\
\hline$"$ & D. capensis & $\mathrm{T} 2$ & T1 & Erect \\
\hline$"$ & D. madagascariensis & $\mathrm{T} 2$ & $\mathrm{T1}$ & Erect \\
\hline$"$ & D. ramentacea & $\mathrm{T} 2$ & $\mathrm{~T} 1$ & Erect \\
\hline$"$ & D. rotundifolia & $\mathrm{T} 2$ & $\mathrm{~T} 2$ & Basal rosette \\
\hline “ & D. spatulata & $\mathrm{T} 2$ & $\mathrm{~T} 2$ & Basal rosette \\
\hline Ergaleium & D. erythrorhiza & $\cdots$ & $-\cdots$ & Basal rosette \\
\hline “ & D. bulbosa & $-\cdots$ & $-\cdots$ & Basal rosette \\
\hline$"$ & D. lowriei & $-\cdots$ & $\mathrm{T} 1$ & Basal rosette \\
\hline$"$ & D. macrantha & --- & $\mathrm{T} 1$ & Erect \\
\hline$"$ & D. modesta & $-\cdots$ & $\mathrm{T} 1$ & Erect \\
\hline$"$ & D. peltata & $\ldots$ & $\mathrm{T1}$ & Erect \\
\hline Lasiocephala & D. lanata & $\mathrm{T} 2$ & $\mathrm{~T} 1$ & $\begin{array}{c}\text { Rosette, erect } \\
\text { leaves }\end{array}$ \\
\hline$"$ & D. ordensis & $\mathrm{T} 2$ & $\mathrm{~T} 1$ & $\begin{array}{l}\text { Rosette, erect } \\
\text { leaves }\end{array}$ \\
\hline Phycopsis & D. binata & $\mathrm{T} 2$ & $\mathrm{~T} 1$ & $\begin{array}{l}\text { Rosette, erect } \\
\text { leaves }\end{array}$ \\
\hline Prolifera & D. adelae & $--\cdot$ & $\begin{array}{c}\text { resemblance } \\
\text { with T1 }\end{array}$ & Basal rosette \\
\hline$"$ & D. prolifera & -- & --- & $\begin{array}{l}\text { Rosette, erect } \\
\text { leaves }\end{array}$ \\
\hline " & D. schizandra & $\cdots$ & $\cdots$ & Basal rosette \\
\hline Ptycnostigma & D. cistiflora & $\mathrm{T} 2$ & $\mathrm{~T} 1$ & Erect \\
\hline Regia & D. regia & -- & $--\cdot$ & $\begin{array}{l}\text { Rosette, erect } \\
\text { leaves }\end{array}$ \\
\hline Thelocalyx & D. burmannii & $\mathrm{T} 2$ & $\mathrm{~T} 2$ & Basal rosette \\
\hline " & D. sessilifolia & $\mathrm{T} 2$ & $\mathrm{~T} 2$ & Basal rosette \\
\hline
\end{tabular}


assigned to section D rosera showing rectangular heads is D. spatulata. B ut both D. burmannii and D. spatulata also grow further north in A sia and seem to be not typical of A ustralians. The clear majority there show round to slightly oval heads.

M ost of the species growing in the A mericas are assigned to section D rosera. U nfortunately, we had only few plants to examine, but it's interesting that several species like D. montana, D. capillaris, D. felix, but also young plants of D. ascendens and D. villosa (the last two species have only T1-tentacles when matured) show a somewhat more three-cornered than true rectangular shape, which seems to be an A merican feature. But, as in A ustralia, we find also a few species that do not fit. D rosera sessilifolia (section Thelocalix) is only hard to distinguish from $D$. burmannii in A ustralasia and its snap-tentacles move with the same speed. The recently discovered D. meristocaulis (section M eristocaulis) develops snap-tentacles and is surprisingly very similar to the Australian pygmy D rosera. D rosera rotundifolia growing only in colder climates from N orth A merica through Europe and Siberia to J apan shows more rectangular heads.

M ost of the A frican species are also assigned to section D rosera, but D. admirabilis, D. aliciae, D. cuneifolia, and most of the other examined plants possess large rectangular T2-tentacle heads like $D$. rotundifolia or $D$. spatulata. In this connection also, the rectangular heads of $D$. burmannii (A ustralasia) and D. sessilifolia (South A merica) should be mentioned again. A good example for the development of modern tentacles during the maturation of erect plants is the South A frican D. cistiflora (section Ptycnostigma) which has first round, later drop-shaped T2-heads as Iong as it grows as basal rosette, but only two or three leaf-generations after the erect growth started, only sticky T1-tentacles appear in their place.

Looking at the morphology, the majority of species in Australia develop round-shaped T2heads; in A frica, we find mainly rectangular heads; and in the A mericas, the lower part of the cushion-like cellstructure is often a little smaller than the upper part, so they appear more wedgeshaped. That looks very much like a separated development on each continent, but from common ancestors. A development, that is similar and well known al so from other plant genera (i.e. Proteaceae), was caused by the continental shift which separated the southern continents more than 100 million years ago. If this can be confirmed by other scientific methods for the genus D rosera, we have- even without usable fossils - a good evidence that carnivory is actually a very old strategy within the plant kingdom, existing even in Gondwana, the giant continent in the Southern Hemisphere which broke apart into A ntarctica, A ustralia, A frica, India, and South A merica between 130 - 100 million years ago, so the archaic sundews must even be considerable older. This theory would also provide a logical explanation for the occurrence of obviously closely related species on different (now) remote continents.

\section{Conclusion}

If we summarize all of the observations mentioned above and combine them with scientific confirmed incidents, a surprising theory (to be confirmed by other scientific disciplines) can be expounded:

Once upon a time, 200 or maybe even 300 million years ago, archaic vertebrates, plants, and arthropods like millipedes, insects, mites, and spiders, were living in the tropical rainforests at the southern coastal regions of Gondwana, an area that corresponds today mainly with A ntarctica, but also the southern tip of South A merica in the west and A ustralia in the east. Certainly different from today, but following the same principles of life as nowadays, food chains and a web of interdependence including mutualism and parasitism developed. This interrelation en- 
abled a group of early angiosperms (flowering plants) to use the manifold arthropods for their sexual reproduction. Compared with pollination by wind, animal-assisted pollination is much more beneficial because only a fraction of the pollen is necessary if it is carried by animals specific to the females. As a result, the modern insect-attracting flowers and a new web of interdependences developed.

Today all known carnivorous plants are angiosperms, so it is only logical to consider that they also realized very soon that arthropods attracted by provided nectar are not only good to transport pollen, but are also compact protein-packs which can be used very efficiently as nutrients, providing a certain advantage on poor rainforest soils. Therefore, some angiosperms started to catch prey with sticky tentacles on the surface of their leaves (and others probably also with pitcher forming leaves) and learned in the course of time to produce digesting enzymes and glands to absorb the nutrients. Thus, the archaic sundews, looking probably somewhat like D. schizandra or D. regia started their successful existence.

A bout 130-140 million years ago, these archaic D rosera had conquered the whole south of Gondwana, but now some wasps decided to settle on the ground and to use wings only for their mating flights. As a result, one of the most successful genera on earth appeared: the ants. Without a doubt, the appearance of ants caused a kind of revolution for all organisms living on the ground. Even today, it can be frequently observed that ants, which are certainly also prey for D rosera, steal considerable amounts of prey that the sticky plants caught. So, with the ants, the quantity of nutrients became suddenly seriously reduced. The ability to roll in leaves to hold captured prey more effectively and to increase the surface for digestion was too slow to avoid the theft by the omnipresent ants (and/or other clepto-parasites). B ut as part of the never ending story in nature to become the fittest survivor, some D rosera developed marginal tentacles equipped with a powerful broad base and the ability to move rapidly enough to fix the prey effectively before predatory ants are able to steal it. With this successful adaptation, the modern Drosera saw the light of day. During the following millions of years, new Drosera species and even two new genera changed the sticky and snap-tentacle armed trap into a closing snap-trap (which is even more effective to prevent the theft of prey), prospered well and proliferated north.

Caused by the continental shift, Gondwana broke asunder into the new southern continents and as early as 100 million years ago, the oceans in between became so large that the now separated species on the divided landmasses developed independent from each other. Antarctica, the area where probably the first $D$ rosera developed, became isolated in the polar region and the archaic life was killed by frost. A ustralia, the last continent that broke away from the east of A ntarctica drifted toward the equator and carried so many Gondwana species, like the marsupials, that it is now the epicenter with the most descendants of archaic and modern Drosera. South A merica broke away from the west of A ntarctica earlier, but different species like D. sessilifolia and D. meristocaulis, with obviously closely related plants in A ustralia, may be evidence for common ancestors in $\mathrm{G}$ ondwana. A Iso, in South A frica, which separated even earlier, D. indica and numerous modern species survived, including the most archaic D. regia, which has several similarities with the A ustralian (and New Zealand) D. arcturi.

When our first observations and investigations on the movement and different shapes of elongated marginal tentacles started, it was interesting from the beginning, but we never expected how much new information can be collected even today using a simple microscope. M ost of our published results have meanwhile been confirmed and supplemented by other CP-experts and authors. However, as mentioned before, our conclusion supporting the so called "Gondwana theory" should soon be confirmed by other scientific disciplines. 
A cknow ledgements: The following persons, listed inal phabetical order, provided hel pful comments or other assistancein the preparation of this paper: Greg B ourke, R ichard Davion, Christian D iet, A ndreas Fleischmann, A nja \& H olger Hennern, Regina Kettering, Elvis Pöhlmann, B arry Rice, Jan Schlauer, Stephen Williams, and some more anonymous contributors.

\section{References}

Darwin, C. 1888. Insectivorous Plants. $2^{\text {nd }}$ edition, revised by Francis Darwin. J ohn M urray, L ondon. Davion, R. 1995. N ow you see it - N ow you don't. Flytrap News (CPSN SW ) 8/4: 17.

Davion, R. 1999. That damned elusive Pimpernel. Flytrap N ews (CPSNSW) 13/1: 10.

E rickson, R. 1968. Plants of Prey. U niversity of Western A ustralia Press, N edlands.

Fenner, C.A . 1904. B eiträge zur K enntnis der A natomie, Entwicklungsgeschichte und Biologie der L aubblätter und D rüsen einiger Insektivoren. Flora 1904, 93 B and.

Hartmeyer, S. 2003. N eues vom Sonnentau: Die Sektion Arachnopus unter dem M ikroskop. Das Taublatt (GFP) 2003/3: 4-8

Hartmeyer, S. 2004. D rosera section Arachnopus under the microscope. Carniflora A ustral is (AUS-

CPS) 2004/3: 11-17. (modified English translation, published in A ustralia).

Hartmeyer, I., and Hartmeyer, S. 2004. Q uer durch's Karnivorenbeet. (English: A H unting Veggies Cocktail), DV D

Hartmeyer, I., and Hartmeyer, S. 2005. D rosera glanduligera: Der Sonnentau mit, "Schnapp-Tentakeln". Das Taublatt (GFP) 2005/2: 34-38.

Hartmeyer, I. and Hartmeyer, S. 2006a. Verborgene V ielfalt: Die Schnelltentakel der Gattung D rosera. Das Taublatt (GFP) 2006/1: 38-50.

Hartmeyer, I., and Hartmeyer, S. 2006b. Clandestine diversity: Snap-tentacles of genus D rosera. Carniflora A ustralis (AUSCPS) 2006/No 7:4-18. (modified English translation, published in A ustralia).

H artmeyer, I., and Hartmeyer, S. 2006c. La diversità nascosta: i tentacoli a scatto nel genere D rosera

- Traduzione italiana di Chiara dB. A IPC M agazine (A IPC) 2006/3:14-25. (I talian translation by Chiara dB, published in I taly).

Hartmeyer, I., and Hartmeyer, S. 2006d. D rosera - Snap-Tentacles and Runway-Lights (German language: D rosera - Schnelltentakel und L andescheinwerfer), DV D.

H artmeyer, I., and Hartmeyer, S. 2006e. D rosera hartmeyerorum - Der Sonnentau mit Lichtreflektoren. Das Taublatt (GFP) 2006/3: 4-9.

Hartmeyer, I., and Hartmeyer, S. 2008a. Urtümliche und moderne Tentakel unter dem M ikroskop. Das Taublatt (GFP) 2008/3: 36-43.

Hartmeyer, I., and Hartmeyer, S. 2008b. Triple E meets Triphyophyllum (German language: Triple E trifft Triphyophyllum), DV D.

Hooker, J r., H.D. 1917. M echanics of movement in D rosera rotundifolia. Bul. Torrey B ot. Club 44: 389-403.

J uniper, B.E., Robins, R.J., and J oel, D.M. 1989. The Carnivorous Plants. A cademic Press, L ondon: 303.

Lowrie, A. 1989. Carnivorous Plants of A ustralia. Vol. 2 and 3. U niversity of Western A ustralia Press, Nedlands.

M cPherson, S. 2008. Glistening Carnivores - The Sticky-L eaved Insect-Eating Plants. Redfern Natural History Productions. Poole, Dorset, England

Ragetli, H.W.J., Weintraub, M., and Ester L 0. 1972. Characteristics of D rosera tentacles. I. A natomical and cytological detail. Can. J. B ot. 50: 159-168. 
Schlauer, J. 1996. A dichotomous key to the genus D rosera L. (D roseraceae), Carniv. PI. Newslett. 25: $67-88$.

Schlauer, J. 2001. D rosera hartmeyerorum spec. nov (Droseraceae), a new sundew in sect. Arachnopus from Northern A ustralia. Carniv. PI. N ewslett. 30: 104-106.

Williams, S.E. 1976. Comparative sensory physiology of the Droseraceae - the evolution of a plant sensory system. Proc. A mer. Philos. Soc. 120(3): 187-204.

Williams, S.E. 2002. Comparative physiology of the Droseraceae sensu stricto - How do tentacles bend and traps close? Proc. 4th Intl. Carniv. PI. Conf., Tokyo: 77-81.

Williams, S.E., and Pickard, B.G. 1974. Connections and barriers between cells of D rosera tentacles in relation to their electrophysiology. Planta (B erl.) 116: 1-16.

Williams, S.E., and Pickard, B.G. 1979. The role of action potentials in the control of capture movements of D rosera and Dionaea. Plant Growth Substances. Springer Verlag, B erlin-H eidel bergNew York.

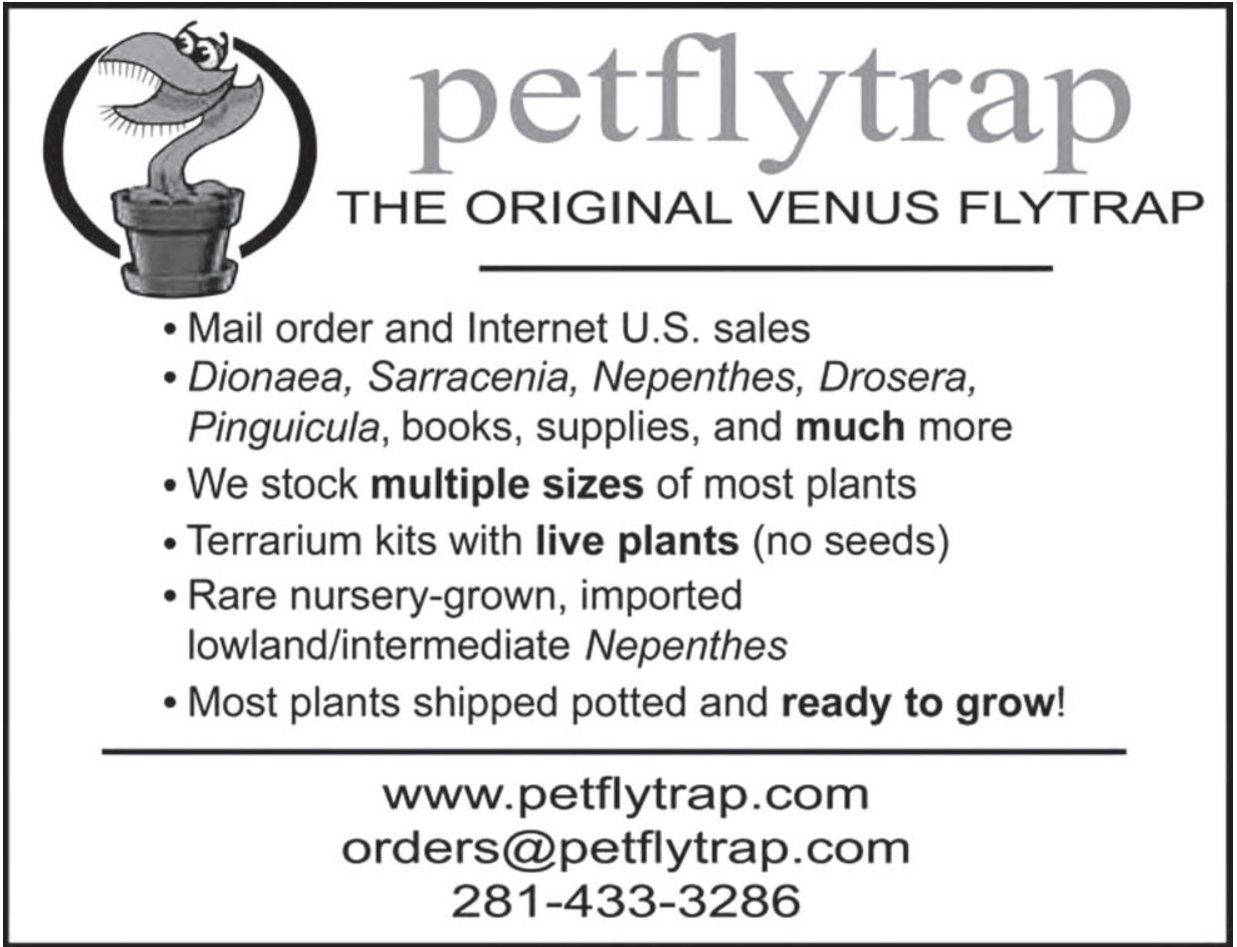




\section{CARNIVOROUS PLANT NEWSLETTER}

Journal of the International Carnivorous Plant Society

Volume 39, No. 4

December 2010

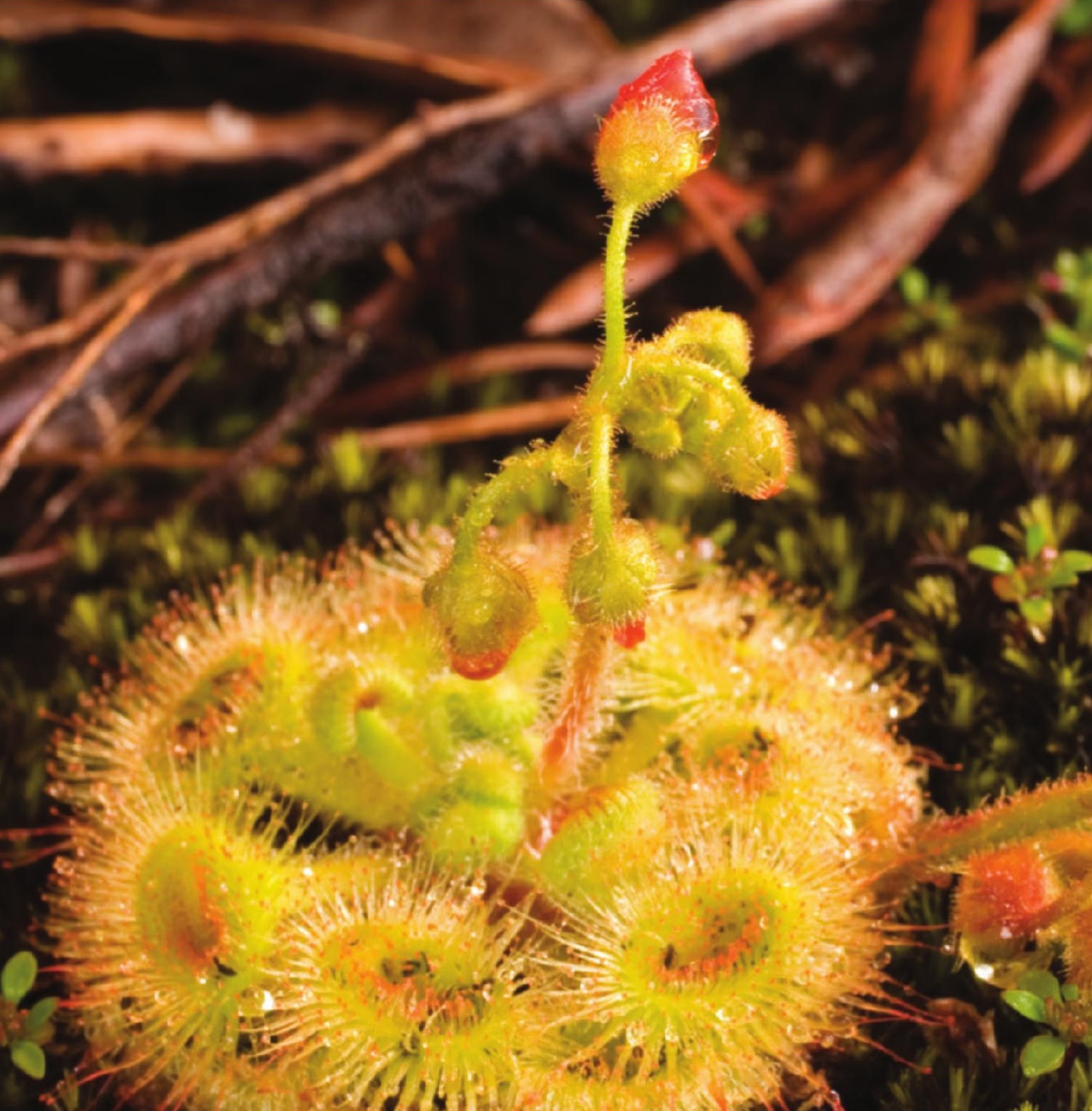

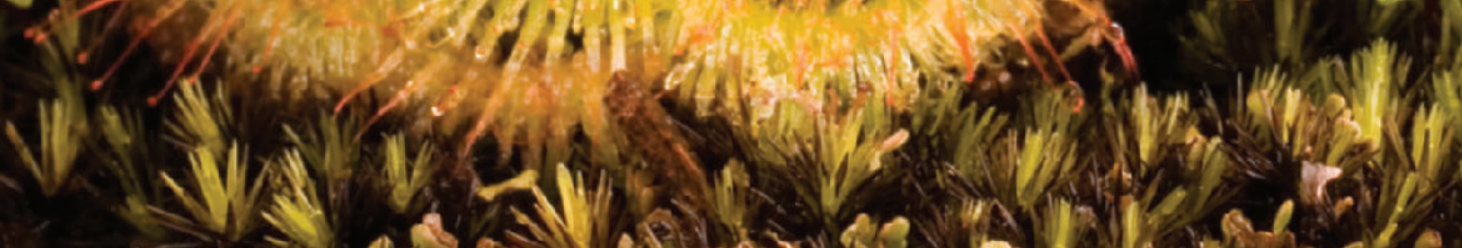
When 


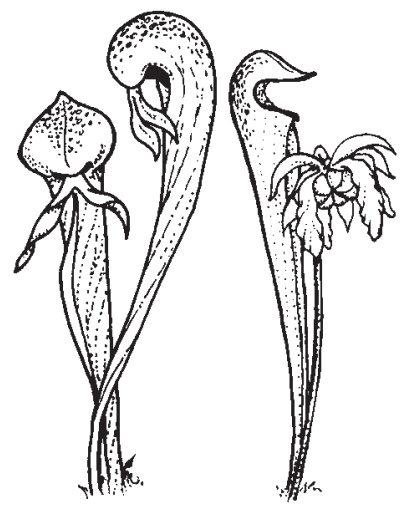

\section{CARNIVOROUS \\ PLANT \\ NEWSLETTER}

Journal of the International

Carnivorous Plant Society

www.carnivorousplants.org

Volume 39, Number 4 December 2010

\section{Front Cover: The Australian Pimpernel Sundew (Drosera glanduligera) in Western Australia. Photo by Barry Rice. Article on page 101.}

\section{Back Cover: A Genlisea bouquet of G. pygmaea (yellow), G. hispidula (lilac), G. violacea (purplish). Photo by Barry Rice. Article on page 114.}

Carnivorous Plant N ewsletter is dedicated to spreading knowledge and news related to carnivorous plants. Reader contributions are essential for this mission to be successful. Do not hesitate to contact the editors with information about your plants, conservation projects, field trips, or noteworthy events. A dvertisers should contact the editors. Views expressed in this publication are those of the authors, not the editorial staff.

All correspondence regarding dues, address changes and missing issues should be sent to the Membership Coordinator at the ICPS. Do not send such correspondence to the editors. Checks for subscriptions should be made to the ICPS in US funds. Dues for 2011 are \$35 for the first year of membership; renewals are \$30 per year.
ICPS, Inc.
PM B 322
1564-A Fitzgerald Drive
Pinole, CA 94564-2229, USA
icps@carnivorousplants.org

$\begin{array}{ll}\text { President } & \text { M ichael Baldwin, michael@ carnivorousplants.org } \\ \text { Vice President } & \text { Marcel van den B roek, marcel@ carnivorousplants.org } \\ \text { Secretary } & \text { Cindy Slezak, cindy@ carnivorousplants.org } \\ \text { Treasurer } & \text { Richard M yers, richard@ carnivorousplants.org } \\ \text { B oard M ember } & \text { B ob Ziemer, bob@ carnivorousplants.org } \\ \text { B oard M ember } & \text { Jan Schlauer, jan@ carnivorousplants.org } \\ \text { B oard M ember } & \text { B Bian B arnes, Conservation Director, brian@ carnivorousplants.org } \\ \text { Seed Bank M anager } & \text { John B rittnacher, john@ carnivorousplants.org (see seed bank ad in this issue) }\end{array}$

Editors:

M anaging Editor Bob Ziemer, bob@carnivorousplants.org

Science Editor Jan Schlauer, jan@ carnivorousplants.org

Science Editor $\quad$ Fernando Rivadavia, fernando@ carnivorousplants.org

Editor

Barry Rice, barry@ carnivorousplants.org

Date of effective publication of the September 2010 issue of Carnivorous Plant N ewsletter: 1 September 2010.

The ICPS is the International Cultivar Registration A uthority (ICRA) for the names of cultivated carnivorous plants according to the International Code of N omenclature for Cultivated Plants. Send relevant correspondence to the ICPS, Inc.

PU BLISHER: ICPS, Inc., Pinole, California. Published quarterly with one volume annually. Printed by A llen Press, Inc., 810 E. 10th Street, L awrence, KS 66044. L ogo and masthead art: Paul M ilauskas.

Dues for 2011 are $\$ 35$ for the first year of membership; renewals are $\$ 30$ per year.

c 2010 Carnivorous Plant N ewsletter. All rights reserved. ISSN \#0190-9215 